\title{
Dissociation between the circulating renin-angiotensin system and angiotensin II receptors in central losartan-induced hypertension
}

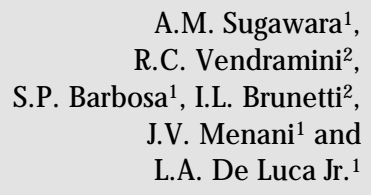

A.M. Sugawara ${ }^{1}$

R.C. Vendramini²,

S.P. Barbosa ${ }^{1}$ I.L. Brunetti ${ }^{2}$,

J.V. Menani ${ }^{1}$ and

L.A. De Luca Jr. ${ }^{1}$

\begin{abstract}
${ }^{1}$ Departamento de Fisiologia e Patologia, Faculdade de $O$ dontologia, and ${ }^{2}$ Departamento de Análises Clínicas, Faculdade de Ciências Farmacêuticas, Universidade Estadual Paulista, Araraquara, SP, Brasil
\end{abstract}

\section{Correspondence \\ L.A. De Luca Jr. \\ Departamento de Fisiologia e \\ Patologia \\ Faculdade de O dontologia, UNESP \\ Rua Humaitá, 1680 \\ 14801-903 Araraquara, SP \\ Brasil \\ Fax: +55-16-201-6314 \\ E-mail: lucajr@ foar.unesp.br \\ Presented at the IV International Symposium on Vasoactive Peptides, Belo Horizonte, MG, Brazil, O ctober 19-21, 2001. \\ Research supported by CNPq- PRONEX, FAPESP and FUNDUNESP. \\ A.M. Sugawara was the recipient of a graduate fellowship from FAPESP.}

Received December 7, 2001 Accepted August 2, 2002

\section{Abstract}

Losartan, an $\mathrm{AT}_{1}$ angiotensin II (ANG II) receptor non-peptide antagonist, induces an increase in mean arterial pressure (MAP) when injected intracerebroventricularly (icv) into rats. The present study investigated possible effector mechanisms of the increase in MAP induced by icv losartan in unanesthetized rats. Male Holtzman rats (280-300 g, $\mathrm{N}=6$ /group) with a cannula implanted into the anterior ventral third ventricle received an icv injection of losartan $(90 \mu \mathrm{g} / 2 \mu \mathrm{l})$ that induced a typical peak pressor response within $5 \mathrm{~min}$. In one group

Key words

- Angiotensin II

- $\alpha_{1}$-Adrenoceptors

- Arterial pressure

- $\mathrm{AT}_{1}$ receptors

- Angiotensin-converting enzyme

- Renin of animals, this response to icv losartan was completely reduced from $18 \pm 1$ to $4 \pm 2 \mathrm{mmHg}$ by intravenous (iv) injection of losartan (2.5-10 $\mathrm{mg} / \mathrm{kg}$ ), and in another group, it was partially reduced from $18 \pm 3$ to $11 \pm 2 \mathrm{mmHg}$ by iv prazosin $(0.1-1.0 \mathrm{mg} / \mathrm{kg})$, an $\alpha_{1}$-adrenergic antagonist $(\mathrm{P}<0.05)$. Captopril $(10 \mathrm{mg} / \mathrm{kg})$, a converting enzyme inhibitor, injected $i v$ in a third group inhibited the pressor response to icv losartan from $24 \pm 3$ to $7 \pm 2 \mathrm{mmHg}(\mathrm{P}<0.05)$. Propranolol $(10 \mathrm{mg} /$ $\mathrm{kg}$ ), a $\beta$-adrenoceptor antagonist, injected $i v$ in a fourth group did not alter the pressor response to icv losartan. Plasma renin activity and serum angiotensin-converting enzyme activity were not altered by $i c v$ losartan in other animals. The results suggest that the pressor effect of icv losartan depends on angiotensinergic and $\alpha_{1}$-adrenoceptor activation, but not on increased circulating ANG II.

\section{Introduction}

The $\mathrm{AT}_{1}$ angiotensin II (ANG II) receptor antagonist losartan induces an increase in arterial pressure when injected into the brain ventricular system (1-3). Activation of brain ANG II receptors is traditionally associated with an increase in arterial pressure $(4,5)$, but there are also reports of a decrease in arterial pressure induced by exogenous ANG II (for a review, see Ref. 3). Thus, the hypertensive effect of central losartan is explained, at least in part, by its action on central depressor ANG II receptors. However, nothing is known about the efferents that mediate this effect of central losartan. Thus, in the present study we determined whether sympathetic output and the systemic renin-angiotensin system mediate the pressor effect induced by losartan injected into the third cerebral ventricle ( $3 r d V)$. 


\section{Material and Methods}

\section{Animals}

Male Holtzman rats weighing 260-300 g at the beginning of the experiment were individually housed in a room on a 12:12-h light/dark cycle beginning at 7:00 am. Standard Purina (Campinas, SP, Brazil) pellets and tap water were available ad libitum unless otherwise stated. All experiments began at 8:00 am.

\section{Brain surgery and histology}

Each animal received a stainless steel guide cannula ( $0.7 \mathrm{~mm} \mathrm{OD)} \mathrm{stereotaxically}$ implanted into the anterior part of the $3 \mathrm{rdV}$ under tribromoethanol (Aldrich Chemical Company Inc., Milwaukee, WI, USA) anesthesia (20 mg/100 g body weight). Coordinates for the anteroventral $3 \mathrm{rdV}$ were: 0.2 $\mathrm{mm}$ caudal to bregma, $6.6 \mathrm{~mm}$ from duramater, $1.2 \mathrm{~mm}$ lateral to sagittal suture, incisor bar $2.5 \mathrm{~mm}$ below the interaural line, and cannula at an angle of $10^{\circ}$ from the sagittal plane. A prophylactic dose of penicillin $(30,000 \mathrm{IU})$ was administered $\mathrm{im}$ before surgery. At the end of the experiments, the animals were deeply anesthetized with chloral hydrate $(800 \mathrm{mg} / 100 \mathrm{~g}$ body weight) and perfused with $10 \%$ formalin through the left ventricle of the heart. The brain was removed, fixed in $10 \%$ formalin, frozen and sectioned for light microscopy examination.

\section{Drugs and injection techniques}

Losartan $(90 \mu \mathrm{g})$ was injected into the $3 \mathrm{rdV}$ in a volume of $2 \mu \mathrm{l}$. Single pulse intracerebroventricular (icv) injections were made with an injector $(0.3 \mathrm{~mm}$ OD) that protruded $1.0 \mathrm{~mm}$ beyond the tip of the guide cannula. Prazosin hydrochloride, an $\alpha_{1}$-adrenergic antagonist $(0.1$ and $1.0 \mathrm{mg} / \mathrm{kg}$ ), propranolol hydrochloride, a $\beta$-adrenergic antagonist (10 $\mathrm{mg} / \mathrm{kg}$ ), losartan, an $\mathrm{AT}_{1} \mathrm{ANG}$ II receptor antagonist $(1.25,2.5,5.0$ and $10.0 \mathrm{mg} / \mathrm{kg})$, captopril, an angiotensin-converting enzyme (ACE) blocker $(10 \mathrm{mg} / \mathrm{kg})$, or $0.9 \%$ saline was injected intravenously (iv) 20 min before the $i c v$ injection of losartan through a catheter previously implanted into the right jugular vein. Except for losartan (a gift from Dr. Ronald D. Smith, DuPont-Merck, Wilmington, DE, USA), all other drugs were purchased from Sigma (St. Louis, MO, USA). Each drug was dissolved or suspended (prazosin) in $0.9 \%$ saline.

\section{Measurement of plasma renin and serum angiotensin-converting enzyme activities}

Plasma renin activity was measured by radioimmunoassay. One hundred microliters of each plasma sample was mixed with $200 \mu \mathrm{l}$ of $0.2 \mathrm{M}$ Tris- $\mathrm{HCl}$ buffer, $\mathrm{pH} 7.4,20$ $\mu 1$ of $48 \mathrm{mM} 8-\mathrm{OH}$-quinoleine and $10 \mu \mathrm{l}$ of $161 \mathrm{mM}$ phenylmethylsulfonyl fluoride and incubated at $37^{\circ} \mathrm{C}$ for $3 \mathrm{~h}$. Blanks were prepared by incubating the plasma samples under the same conditions at $4{ }^{\circ} \mathrm{C}$. After incubation, the amount of ANG I generated from angiotensinogen was determined by radioimmunoassay. The linear range of the method extends from plasma renin activity values of 0.3 to $11 \mathrm{ng} \mathrm{ml}^{-1} \mathrm{~h}^{-1}$.

Serum ACE activity was measured by coupling an indicator reaction, catalyzed by $\gamma$-glutamyltransferase, to the ACE-catalyzed hydrolysis of hippuryl-glycyl-glycine (6). ACE activity was calculated from the production of the chromophore 3-carboxy-4nitroaniline, determined with a spectrophotometer at $410 \mathrm{~nm}$, and defined as $\mu \mathrm{mol}$ hippuric acid, and therefore of glycyl-glycine (coupler), released by one liter of serum per minute (U/l). The increase in absorbance due to the formation of 3-carboxy-4-nitroaniline in the $\gamma$-glutamyltransferase reaction was linear to the concentration of glycylglycine and therefore to the activity of ACE. The linear range of the method extends from 
ACE values less than 50 to $1300 \mathrm{U} / 1$.

\section{Arterial pressure recording}

Four days after surgery, the animals were anesthetized with tribromoethanol $(20 \mathrm{mg} /$ $100 \mathrm{~g}$ body weight), a catheter was fitted into the femoral artery and another one into the right jugular vein. Both catheters were tunneled subcutaneously and exteriorized at the nape of the neck. On the next day, the femoral catheter was connected to a Narco (P1000B) pressure transducer coupled to a multichannel recorder (Narcotrace 40, Narco Bio-System, Austin, TX, USA). Direct mean arterial pressure (MAP) was recorded from the abdominal aorta in unanesthetized, unrestrained, normovolemic rats. Baseline was defined when MAP remained stable for at least $5 \mathrm{~min}$ of continuous recording before any treatment. Each animal was submitted to only one day of cardiovascular recording.

\section{Statistical analysis}

Peak variations in arterial pressure, which occurred up to $5 \mathrm{~min}$ after the icv injection of losartan, were submitted to analysis of variance followed by the post hoc Student-Newman-Keuls test. Dose zero of the antagonists corresponds to $0.9 \%$ saline. The unpaired $t$ test was used for analysis of the biochemical plasma renin and ACE activity data. Data are reported as means \pm SEM and the level of significance was set at $\mathrm{P}<0.05$. A minimum of six animals were used in each group. Each animal submitted to arterial pressure recordings received only two $i c v$ injections separated by a 6-h interval. Blood for plasma renin and ACE was collected on the same day from both treated and control animals.

\section{Experimental protocols}

Antagonists or enzyme blocker iv + losartan icv. Different doses of the antagonists were randomly assigned to each experimen- tal day. Half of the animals received one dose of the antagonists in the first injection and half received the other dose. Then, the doses given were reversed in the second injection given at least $6 \mathrm{~h}$ later. The antagonists were injected $i v$ immediately after the baseline recording, $20 \mathrm{~min}$ before $i c v$ injection of losartan.

Effects of icv losartan on plasma renin and ACE activity. A group of 16 animals received an icv injection of losartan $(90 \mu \mathrm{g})$ or isotonic saline and were left in their home cages for $5 \mathrm{~min}$ before decapitation. This interval includes the peak pressor response to icv losartan $(1,3)$. Trunk blood was collected from each animal into chilled tubes containing either $7.5 \%$ EDTA $(100 \mu \mathrm{l} / \mathrm{ml})$ for collection of plasma or gel separator (Becton Dickinson, Plymouth, UK) for collection of serum. Plasma was obtained from whole blood centrifuged at $3,000 \mathrm{rpm}$ at $4^{\circ} \mathrm{C}$ for $15 \mathrm{~min}$. Plasma and serum were then processed for determination of plasma renin and ACE activity, respectively.

\section{Results}

\section{Effects of icv injection of losartan on arterial pressure}

Losartan $(90 \mu \mathrm{g})$ injected $i c v$ induced a peak pressor response of $20 \pm 4 \mathrm{mmHg}$ within 5 min compared to a $1 \pm 1 \mathrm{mmHg}$ response to $i c v$ saline $(\mathrm{N}=14$ /group, $\mathrm{P}<0.05)$.

\section{Effects of antagonists or the enzyme blocker injected iv on the pressor response to losartan injected into the 3rdV}

Losartan $(1.25,2.5,5.0$ and $10.0 \mathrm{mg} / \mathrm{kg})$ iv produced 80 to $100 \%$ inhibition of the peak pressor response to $i c v$ losartan (Figure 1). Captopril $(10 \mathrm{mg} / \mathrm{kg})$ injected $i v$ induced a $70 \%$ inhibition of the pressor response to icv losartan (Figure 2).

Prazosin $(0.1$ and $1.0 \mathrm{mg} / \mathrm{kg})$ injected $i v$ produced an inhibition of $46 \%$ in the pressor 
Figure 1. Effect of intravenous injection of losartan on the pressor response to icv losartan (90 $\mu \mathrm{g})$. The number of animals is given in parentheses. $* \mathrm{P}<0.05$ vs doze zero (Student-NewmanKeuls test). MAP $=$ mean arterial pressure.
Figure 2. Effect of intravenous injection of captopril on the pressor response to icv losartan (90 $\mu \mathrm{g})$. $\mathrm{N}=7$ for each group. $* \mathrm{P}<0.05$ vs doze zero (StudentNewman-Keuls test). MAP = mean arterial pressure.
Figure 3. Effect of intravenous injection of prazosin on the pressor response to icv losartan (90 $\mu \mathrm{g})$. The number of animals is given in parentheses. ${ }^{*} \mathrm{P}<0.05$ vs doze zero (Student-NewmanKeuls test). MAP $=$ mean arterial pressure.
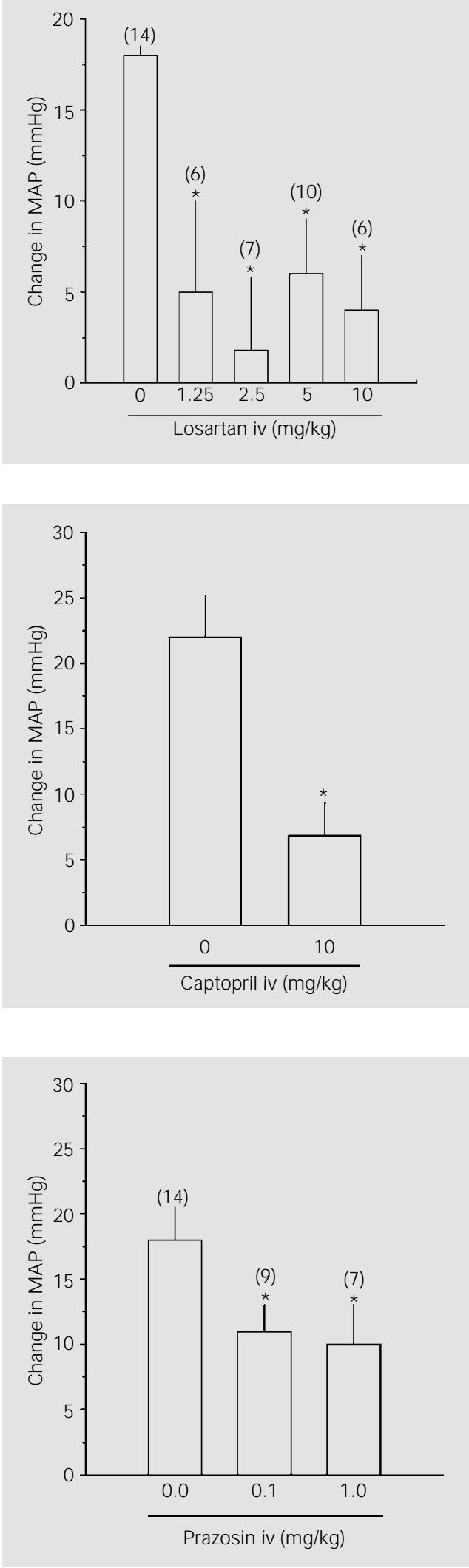

response to icv losartan (Figure 3). Propranolol injected $i v(10 \mathrm{mg} / \mathrm{kg})$ did not alter the pressor effect of $i c v$ losartan (Figure 4).

\section{Effect of icv losartan on plasma renin and ACE activity}

Losartan injected $i c v$ did not alter plasma renin or ACE activity. The values for $90 \mu \mathrm{g}$ losartan-treated $(\mathrm{N}=8)$ and saline-treated $(\mathrm{N}=8)$ rats were $1.8 \pm 0.6$ and $1.8 \pm 0.7 \mathrm{ng}$ ANG $\mathrm{ml}^{-1} \mathrm{~h}^{-1}$ and $535 \pm 45$ and $537 \pm 82$ $\mathrm{U} / 1$, respectively.

\section{Effects of the antagonists injected iv on basal} mean arterial pressure

Basal MAP (Table 1) was reduced by the lowest dose of losartan and by the two doses of prazosin injected $i v$. Captopril and propranolol injected $i v$ did not alter basal MAP.

The lowest dose $(1.25 \mathrm{mg} / \mathrm{kg})$ of losartan is similar to the dose $(1.0 \mathrm{mg} / \mathrm{kg})$ which reduces the pressor effect of systemic ANG II by $50 \%$ (7). This was confirmed by injecting the lowest dose $i v$ prior to $25 \mathrm{ng}$ of $i v$ ANG II. The pressor response to ANG II was reduced from $43 \pm 6$ to $22 \pm 6 \mathrm{mmHg}(\mathrm{P}<0.05$, $\mathrm{N}=4$ ).

The patency of the propranolol solution was confirmed by a fall in heart rate $(-91 \pm$ $15 \mathrm{bpm}, \mathrm{N}=8)$ compared to the effect of $0.9 \%$ saline $(0 \pm 3 \mathrm{bpm}, \mathrm{N}=14)$.

\section{Discussion}

Hypertension induced by icv injection of losartan was reduced by $i v$ injection of losartan, captopril or prazosin, and was not altered by $i v$ injection of propranolol. Intracerebroventricular injection of losartan altered neither plasma renin nor ACE activity.

The increase in arterial pressure induced by icv losartan could result from an action on central $\mathrm{AT}_{1}$ receptors. This is consistent with the less explored hypotensive effect induced by central actions of ANG II. Localization of 
receptor mechanisms and interactions with neurotransmitters related to such effect has been more systematically investigated in the hindbrain. Peptide and non-peptide ANG II antagonists, including losartan, produce sympathoactivation and an increase in arterial pressure when injected into the rostral and the caudal ventrolateral medulla (8-11). Losartan may also interact with catecholamines in the hindbrain to produce sympathoactivation (12). When injected into the 4th ventricle, but not into the anterior ventricles, losartan induces bradycardia $(1,2)$ likely related to the modulatory effect hindbrain ANG II receptors have on baroreflex (8-12). However, better hypertensive effects are obtained with losartan injected into the 3rd than into the 4 th cerebral ventricles in the rat $(1,2)$. Contrary to what has been suggested (12), this effect does not depend on potassium associated with losartan (1). Thus, the hypotensive ANG II receptors accessible through the ventricular route should be found mainly in the forebrain, but scant information is available on how ANG II acts there to produce hypotension $(13,14)$.

The arterial pressure increase induced by losartan injected into the $3 \mathrm{rdV}$ depends, at least in part, on the periventricular tissue surrounding the anteroventral 3rdV (3) which connects through hypothalamic nuclei to the sympathetic system $(15,16)$. Thus, it is possible that the pathway that activates the $\alpha_{1}$ adrenergic receptors mediating the pressor effect of losartan starts in forebrain structures that converge to the intermediolateral column and from there proceed through efferent signals to blood vessels. The sympathetic system also provides efferents to $\beta$ adrenergic receptors of the juxtaglomerular cells to release renin (16) and $B$-adrenergic receptors activate the intrinsic vascular renin-angiotensin system $(17,18)$. Moreover, $\beta$-adrenergic activation in the heart increases cardiac output (16). Nevertheless, ß-adrenergic receptors and the corresponding responses are probably not involved in the

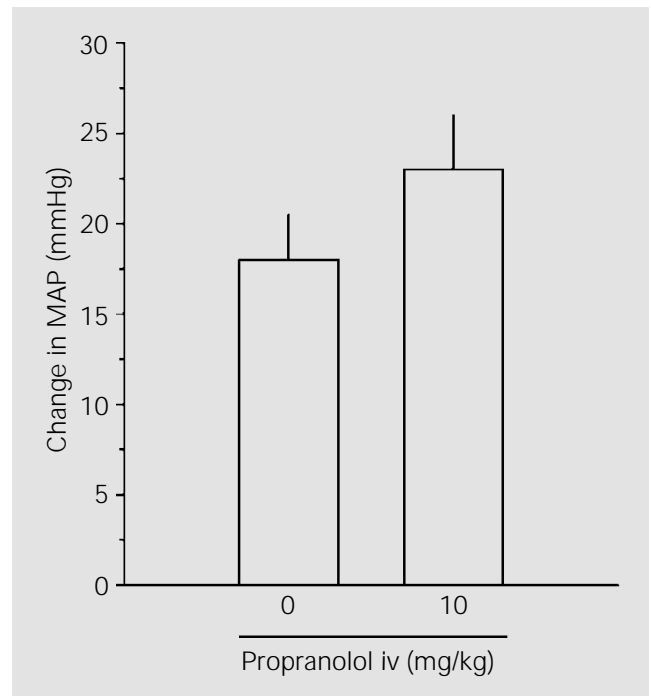

Figure 4. Effect of intravenous injection of propranolol on the pressor response to icv losartan $(90 \mu \mathrm{g}) . \mathrm{N}=8$ for each group. MAP $=$ mean arterial pressure. There was no statistical effect of propranolol (Student-Newman-Keuls test).
Table 1. Peak variation in mean arterial pressure ( $\triangle \mathrm{MAP}$ ) after intravenous injections of $0.9 \%$ saline, losartan, captopril, prazosin or propranolol.

\begin{tabular}{lc}
\hline Treatment & $\Delta \mathrm{MAP}(\mathrm{mmHg})$ \\
\hline 0.9\% Saline $(\mathrm{N}=14)$ & $0 \pm 1$ \\
Losartan, $1.25(\mathrm{~N}=6)$ & $-9 \pm 1^{*}$ \\
Losartan, $2.5(\mathrm{~N}=7)$ & $-4 \pm 3$ \\
Losartan, $5.0(\mathrm{~N}=10)$ & $-6 \pm 2$ \\
Losartan, 10.0 $(\mathrm{N}=6)$ & $-3 \pm 3$ \\
Captopril, 10.0 $(\mathrm{N}=7)$ & $-4 \pm 2$ \\
Prazosin, $0.10(\mathrm{~N}=9)$ & $-21 \pm 3^{*}$ \\
Prazosin, $1.0(\mathrm{~N}=7)$ & $-34 \pm 7^{*}$ \\
Propranolol, $10.0(\mathrm{~N}=8)$ & $0 \pm 3$
\end{tabular}

$* \mathrm{P}<0.05$ compared to $0.9 \%$ saline (Student-Newman-Keuls test). Drug concentrations are reported as $\mathrm{mg} / \mathrm{kg}$.

pressor responses to icv losartan since they were not altered by systemic propranolol.

Central losartan-induced hypertension is possibly also mediated by ANG II receptors since antagonism of the renin-angiotensin system reduced this response. The receptors are likely to be peripheral since clear opposite effects are obtained between $i c v$ and $i v$ injections of losartan (present results and Ref. 2). This implies an elusive efferent activation to the systemic renin-angiotensin system to produce hypertension. The efferents do not depend on $\beta$-adrenergic sympathetic 
output as discussed above or on the increase of circulating ANG II since plasma renin or serum ACE activity were not altered by $i c v$ losartan.

The pressor response to icv losartan results from the activation of $\alpha_{1}$-adrenergic and ANG II receptors. This activation probably depends on increased $\alpha_{1}$-sympathetic output and a bypass of the circulating reninangiotensin system.

\section{Acknowledgments}

The authors thank Reginaldo C. Queiróz, Silvia Foglia and Ana Vítor for technical assistance, and Silvana D. Malavolta for secretarial assistance. We also thank Drs. Robson A.S. Santos, Universidade Federal de Minas Gerais, and Marilene Melo, Serviços de Análises Especializadas, São Paulo, for determinations of plasma renin activity.

\section{References}

1. De Luca J r LA, Barbosa SP, Menani J V, Camargo LAA, Saad WA \& Renzi A (1994). Different effects on rat arterial pressure and heart rate when losartan is injected into the third or fourth ventricle. Brazilian J ournal of Medical and Biological Research, 27: 2681-2687.

2. De LucaJ r LA, Barbosa SP, Sugawara AM \& Menani J V (1996). Effects of intracerebroventricular injections of losartan or PD123319 on arterial pressure and heart rate of sodium replete and sodium deplete rats. Regulatory Peptides, 66: 3135.

3. De Luca J $r$ LA, Sugawara AM \& Menani JV (2000). Brain versus peripheral angiotensin II receptors in hypovolaemia: behavioural and cardiovascular implications. Clinical and Experimental Pharmacology and Physiology, 27: 437-442.

4. Phillips MI (1987). Functions of angiotensin in the central nervous system. Annual Review of Physiology, 49: 413-445.

5. Wright J W \& Harding J W (1992). Regulatory role of brain angiotensins in the control of physiological and behavioral responses. Brain Research Bulletin, 17: 227262.

6. Groff J L, Harp J B \& DiGirolamo M (1993). Simplified enzymatic assay of angiotensin-converting enzyme in serum. Clinical Chemistry, 39: 400-404.

7. Wong PC, Price WA, Chiu AT, Duncia J V,
Carini DJ, Wexler RR, J ohnson AL \& Timmermans PBMWM (1991). In vivo pharmacology of DUP 753. American J ournal of Hypertension, 4 (Part 2): 289S298S.

8. Muratani $\mathrm{H}$, Ferrario $\mathrm{CM} \&$ Averill $\mathrm{DB}$ (1994). Ventrolateral medulla in spontaneously hypertensive rats: role of angiotensin II. American J ournal of Physiology, 264: R388-R395.

9. Fontes $M A$, Pinge $M C$, Naves $V$, Campagnole-Santos MJ, Lopes OU, Khosla MC \& Santos RA (1997). Cardiovascular effects produced by microinjection of angiotensins and angiotensin antagonists into the ventrolateral medulla of freely moving rats. Brain Research, 750: 305-310.

10. Fontes MA, Baltatu O, Caligiorne SM, Campagnole-Santos MJ , Ganten D, Bader $M \&$ Santos RAS (2000). Angiotensin peptides acting at rostral ventrolateral medulla contribute to hypertension of TGR(mREN2)27 rats. Physiological Genomics, 2: 137-142.

11. GaudetEA, Godwin SJ \& Head GA (1988). Role of central catecholaminergic pathways in the actions of endogenous Ang II on sympathetic reflexes. American J ournal of Physiology, 275: R1174-R1184.

12. Averill DB, Tsuchihashi T, Khosla MC \& Ferrario CM (1994). Losartan, nonpeptide angiotensin II-type 1 AT(1) receptor an- tagonist, attenuates pressor and sympathoexcitatory responses evoked by angiotensin II and L-glutamate in rostral ventrolateral medulla. Brain Research, 665: 245252.

13. Nicolaidis S, Ishibashi S, Gueguen B Thornton SN \& De Beaurepaire R (1983). Iontophoretic investigation of identified SFO responsive neurons firing in relation to blood pressure changes. Brain Research Bulletin, 10: 357-363.

14. Milani DMC (1992). Estimulação de mecanismos centrais envolvidos com as respostas hipotensoras à angiotensina II no rato anestesiado. Master's thesis, University of São Paulo, São Paulo, SP, Brazil.

15. J ohnson AK \& Gross PM (1993). Sensory circumventricular organs and brain homeostatic pathways. FASEB J oumal, 7: 678-686.

16. Loewy AD \& Spyer KM (Editors) (1990). Central Regulation of Autonomic Functions. Oxford University Press, New York, NY, USA

17. Cockcroft JR, O'Kane KP \& Webb DJ (1995). Tissue angiotensin generation and regulation of vascular tone. Pharmacology and Therapeutics, 65: 193-213.

18. Zimmerman BG \& Dunham EW (1997) Tissue renin-angiotensin system: a site of drug action? Annual Review of Pharmacology and Toxicology, 37: 53-69. 